\title{
A Case of Parapharyngeal Foreign Bodies Causing Explosion of Polyurethane Foam in Oral Cavity
}

\author{
Seon Uk Lee ${ }^{1}$, Min Chul Park, Hyun Chul Shin ${ }^{2}$ and Sung Min Jin ${ }^{1}$ \\ ${ }^{1}$ Departments of Otorhinolaryngology-Head and Neck Surgery, ${ }^{2}$ Neurosurgery, Kangbuk Samsung Hospital, \\ Sungkyunkwan University School of Medicine, Seoul, Korea
}

폴리우레탄의 구강 내 폭발로 인한 부인두강 이물 1예

이선욱 ${ }^{1} \cdot$ 박민철 $^{1} \cdot$ 신현철 $^{2} \cdot$ 진성민 $^{1}$

성균관대학교 의과대학 강북삼성병원 이비인후과학교실, ${ }^{1}$ 신경외과학교실 ${ }^{2}$

\author{
Received April 29, 2011 \\ Revised June 27, 2011 \\ Accepted July 12, 2011 \\ Address for correspondence \\ Sung Min Jin, MD \\ Department of Otorhinolaryngology- \\ Head and Neck Surgery, \\ Kangbuk Samsung Hospital, \\ Sungkyunkwan University \\ School of Medicine, \\ 78 Saemunan-gil, Jongno-gu, \\ Seoul 110-746, Korea \\ Tel $+82-2-2001-2264$ \\ Fax $+82-2-2001-2273$
}

E-mail strobojin@hanmail.net

\begin{abstract}
Foreign bodies in the upper digestive tract are frequently encountered accidental cases in otolaryngologic fields. Oropharyngeal foreign bodies consisting of polyurethane foam have never been reported. Moreover, foreign bodies penetrating into the parapharyngeal space of neck are rare but when it does, it may also cause extensive neurovascular injuries. Polyurethanes are widely used in manufacturing industries but serious hazards of these materials have not been reported. In this article, we report a man who, presented with foreign bodies that entered as a result of an explosion of polyurethane foam in the oral cavity. The foreign body had entered into the parapharyngeal space, very close to the vertebral artery.
\end{abstract}

Korean J Otorhinolaryngol-Head Neck Surg 2011;54:788-90

Key Words Pharynx $\cdot$ Foreign bodies $\cdot$ Polyurethanes.

\section{서 론}

구강부터 식도 입구에 이르는 부위의 이물은 이비인후과 영 역에서 드물지 않게 발생하는 질환이다. ${ }^{1)}$ 간단하게 제거되는 이물이 있는 반면에, 경부의 부인두강(parapharyngeal space) 을 침범하는 경우는 매우 드물고, 이러한 경우에 신경 및 혈 관의 광범위한 손상을 유발할 수 있다. ${ }^{2-4)}$ 부인두강의 이물은 다양하게 보고되고 있는데 아직까지 폴리우레탄 폼(polyurethane foam)이 흡입된 예는 보고된 바가 없다. 저자들은 작업 중에 구강 내에서 폭발한 폴리우레탄 폼으로 인한 부인두강 의 이물로 내원한 59 세 남자 환자 1 예를 경험하였기에 문헌고 찰과 함께 보고하는 바이다.

\section{증 례}

59세 남자가 내원 2일 전 작업도중에 폴리우레탄 폼 용기
를 치아를 이용하여 열던 중에 폴리우레탄 폼이 구강 내부로 폭발하며 발생한 입 안과 목 안의 이물감 및 가벼운 통증으로 타병원 내원하여 표면의 이물을 제거한 상태로 내원하였다. 과 거력상 20년 전 편도 절제술을 시행 받았으며, 하루 1 갑씩 30 년간의 흡연력이 있고 현재까지 지속하고 있었다.

이학적 검사상 연구개 우측 면에 $2 \times 2 \mathrm{~cm}$ 크기의 부종과 발적을 동반한 궤양성 병변이 위치하였으며 약한 압통이 있 었고, 농성 분비물 등은 관찰되지 않았다(Fig. 1). 비강 및 경부 진찰상의 특이 소견은 관찰되지 않았다. 전신마취하에 병변 및 이물 제거를 계획하였다. 연구개 우측 면의 점막하에 존재하는 이물질을 제거한 후 수술을 마쳤다. 수술 후 1 일째 환자는 퇴원하였고 수술 후 1 주째 추적 관찰 때까지 수술 부 위는 문제 없이 치유되었다. 이후 수술 1 개월째의 추적 관찰 중에 환자는 인후 불편감으로 다시 내원하였다. 이학적 검사 상 우측 후편도지주(posterior pillar of tonsil) 부위의 종창과 농성 분비물이 배출되고 있었다(Fig. 2). 경부 전산화단층촬영 


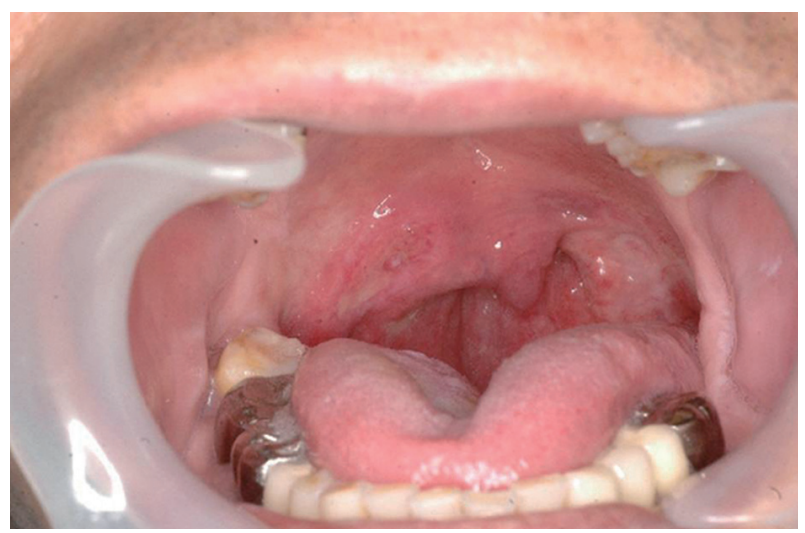

Fig. 1. Initial physical findings. Mucosal swelling on the right side of soft palate was observed, but there were no foreign bodies.

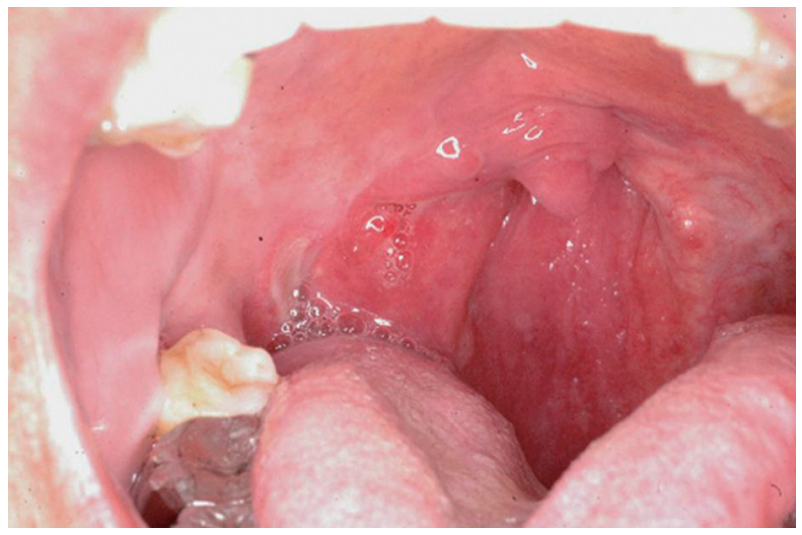

Fig. 2. Physical findings before second operation. Mucosal swelling and purulent discharge were observed in right pillar of tonsil and right side of posterior pharyngeal wall.
을 실시하였고, 구인두의 상부에서 하부까지, 그리고 뒤쪽으 로는 환추-축추 관절(atlanto-axial joint)의 전면까지 퍼져 있는 연부 조직 종창과 기포를 동반하는 염증소견이 우측 부 인두강에서 관찰되었으나 이물질은 명확하게 관찰되지 않았 다(Fig. 3). 염증의 제거와 배농 및 드러나지 않은 점막 하의 이 물질 제거를 위해서 전신마취 하에 수술을 계획하였다. Boyle-Davis 개구기를 걸고 단순도뇨관(nelaton catheter)으로 연 구개를 상방으로 당겨 구인두의 상부와 비인두의 하부를 노 출하였다. 이후 연구개의 상연을 잇는 경계부위의 우측 구인 두 후벽을 따라 $4 \mathrm{~cm}$ 길이의 절개를 하고 점막을 박리하였다. 협인두근막(buccopharyngeal fascia)으로 생각되는 부위를 절개하자 표면이 불규칙하고 비교적 단단한 황색의 이물질이 관찰되었다(Fig. 4A). 이물질은 점막과 유착이 심하였으나 외 측면은 문제없이 잘 박리되었다. 하지만 후면을 박리하는 과정 에서 척추동맥으로 생각되는 부위에서 박동이 느껴져서 신경 외과 협진 수술하여 전척추 부위(prevertebral area)의 손상 없이 제거하였다(Fig. 4B). 이물질은 작은 조각들이 산재해 있 었으며, 그 중 가장 큰 이물질의 장경은 $4 \mathrm{~cm}$ 에 이르렀다(Fig. 5). 충분한 세척 이후 배액관을 삽입한 후 점막 피판을 당겨 봉 합을 시행하고 수술을 마쳤다. 수술 후 항생제 치료 및 창상 관리 이후 8일째 퇴원하였다.

수술 후 2주째에 남아 있는 이물질 및 염증 여부를 위해 경 부 자기공명영상을 시행하였으며 부인두강에서 이물질은 관 찰되지 않았다(Fig. 6). 현재 수술 후 5개월이 지난 상태로 수

Fig. 3. Neck CT with contrast, axial view $(A)$ and sagittal view $(B)$. Soft tissue swelling on the right side of pharyngeal mucosa and soft tissue with low density air bubbles were observed in the oropharyangeal space (white arrow). There was no evidence of the foreign body in the pharynx.
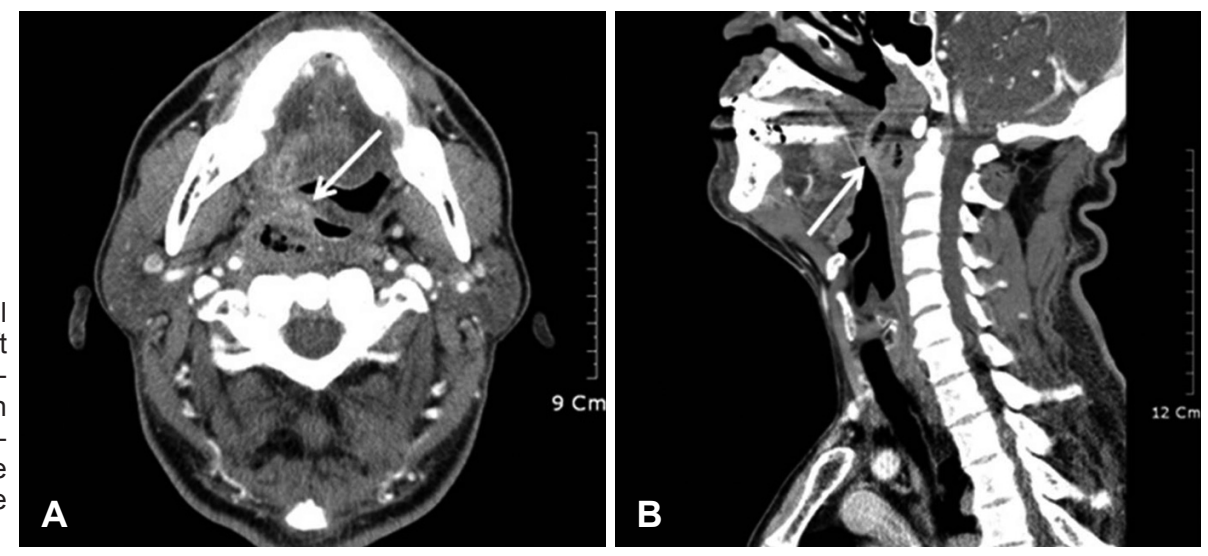

Fig. 4. Intraoperative findings. About $3.5 \mathrm{~cm}$ sized largest foreign body (black asterisk) was extracted from retropharyngeal space in right side of orpharynx ( $A$ and $B$ ).
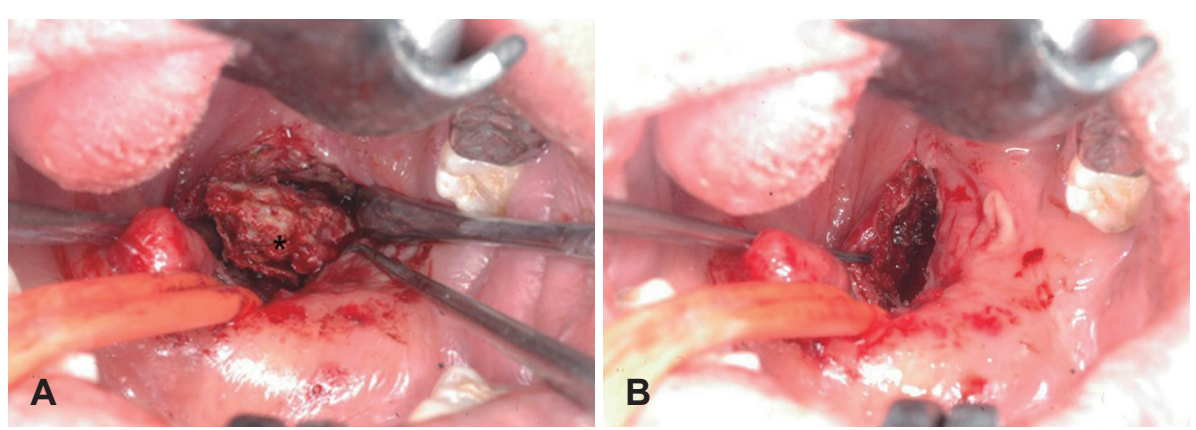


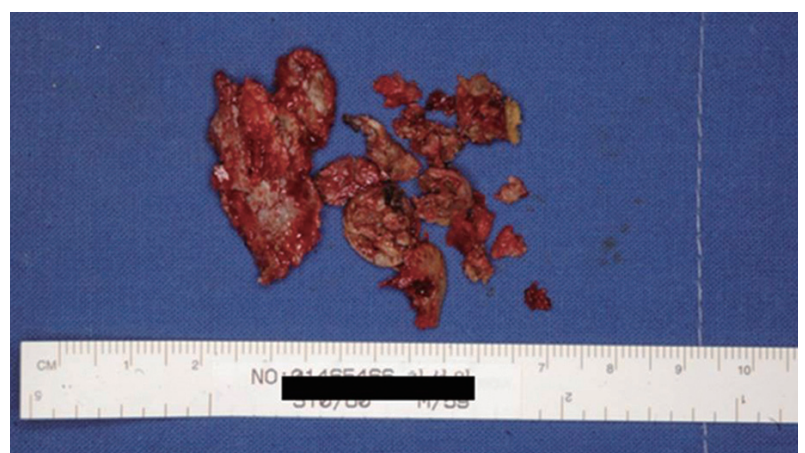

Fig. 5. Extracted foreign bodies. Multiple pieces were extracted out of oropharynx and parapharynx. The longest diameter of the largest one was about $4 \mathrm{~cm}$.

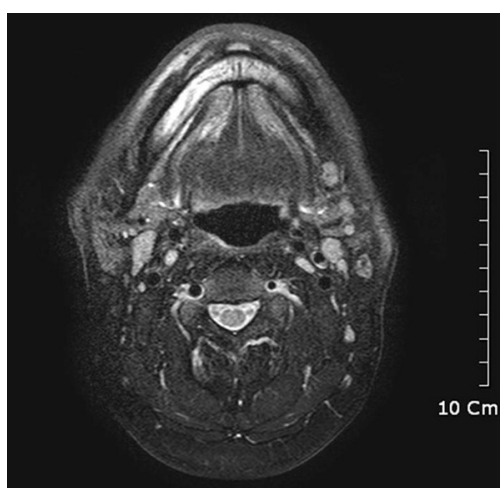

Fig. 6. Neck MRI T2-weighted axial image after the second operation. There were no abnormalities and foreign bodies 2 weeks after the second operation.

술 부위의 문제나 다른 합병증은 없는 상태이다.

\section{고 찰}

부인두강의 이물질에 대해서는 많은 보고들이 존재하지만, 폴리우레탄 폼이 흡입되어 발생한 예는 극히 드문 것으로 생각 된다. Silva 등)에 따르면 128명의 증례 중에서 귀(86명, 67.18\%), 비강(24명, 18.75\%) 및 구인두(18명, 14.07\%)에서 이물질이 있 었다. 이 중에서 구인두의 이물질은 각각 5 명에서 우측 편도, 7 명에서 좌측 편도, 그리고 1명에서 설골 설근 기저(basioglossus)에 위치하였으며, 구인두 이물질에 의한 합병증은 없었다. 관통상에 의한 이물질은 부인두강을 침범하며 심각한 합병증 을 동반하는 경우도 있다. 이러한 이물은 교통사고나 총상 등 으로 발생하는 관통상으로 구강 내의 구치후삼각(retromolar trigone)을 거쳐서 부인두강을 침범하였다. ${ }^{2-4)}$ 이번 증례는 액 체상태의 폴리우레탄 폼이 폭발하며 흡입되어 구인두 및 부인 두강을 침범하였던 경우로서 매우 드문 예로 생각된다.
폴리우레탄은 알코올기와 아이소사이안산기의 결합으로 만 들어진 우레탄결합으로 결합된 고분자 화합물의 총칭이다. 폴 리우레탄에 기포가 들어 있는 형태가 폴리우레탄 폼으로서 전 기절연체, 구조재, 기포단열재, 기포 쿠션 및 탄성섬유 등에 사 용되며, 고무의 대체물질로도 사용된다. 폴리우레탄 폼 자체 는 화학적으로 안전하다고 알려져 있으나 약 $240^{\circ} \mathrm{C}$ 정도의 열 에서 사이안산(cyanic acid), 산화질소(nitrous oxide) 등의 독 성 물질이 방출될 수 있다. ${ }^{5)}$ 유해성에 대해서는 피부 접촉에 관 한 연구 결과와 섭취를 통한 동물 실험 등에 근거하여 독성이 없다고 알려져 있다. ${ }^{6,7)}$ 본 증례에서는 노출 당시에 열로 인한 손상은 환자의 병력상 의심하기 어려우며, 이물질에 노출되었 던 점막의 주변으로 화상은 관찰되지 않았기 때문에 합병증 에 대한 위험성은 적다고 생각되며, 현재 추적 관찰 중에서 특 별한 이상이 관찰되고 있지 않다.

이번 증례에서 환자는 평소 용기를 조작하던 방법 대신에 치아를 이용해서 폴리우레탄 폼 용기를 무리해서 조작하면서 용기가 일부 파손되어 폴리우레탄 폼이 폭발하였다고 생각할 수 있다. 또한 이렇게 금속 용기에 압축되어 있는 물질이 폭발 하면서 발생한 이물의 경우에는 폭발시에 압력이 매우 높기 때문에 손상 부위의 표면뿐만 아니라 심부에 대한 평가가 필 요하다는 것을 알 수 있었다.

저자들은 구인두 및 추골 동맥(vertebral artery)에 근접한 부인두강을 침범한 폴리우레탄 폼으로 이루어진 이물을 경구 개 접근법을 통한 수술로 제거한 환자를 경험하였기에 문헌 고찰과 함께 보고하는 바이다.

\section{REFERENCES}

1) Silva BSR, Souza LO, Camera MG, Tamiso AGB, Castanheira LVR. Foreign bodies in otorhinolaryngology: a study of 128 cases. Intl Arch Otorhinolaryngol 2009;13(4):394-9.

2) Abrol BM, Kapur BM, Raveendran M. Penetrating neck injury (an unusual automobile accident). J Laryngol Otol 1972;86(12):1253-9.

3) Enomoto K, Nishimura H, Inohara H, Murata J, Horii A, Doi K, et al. A rare case of a glass foreign body in the parapharyngeal space: pre-operative assessment by contrast-enhanced CT and three-dimensional CT images. Dentomaxillofac Radiol 2009;38(2):112-5.

4) Bora MK, Narwani S, Mishra P, Bhandari A. A bullet in the parapharyngeal space. Indian J Otolaryngol Head Neck Surg 2003;55(2): 117-9.

5) Polyurethane Exposure Health Alert. Safety and Health Committee. National Stone, Sand and Gravel Association;2004.

6) Dernehl CU. Health hazards associated with polyurethane. J Occup Med 1966;8(2):59-62.

7) Hueper WC. Cancer induction by polyurethane polysilicone plastics. J Natl Cancer Inst 1964;33(6):1005-27. 